\title{
Antibacterial and antilarval compounds from marine gorgonian-associated bacterium Bacillus amyloliquefaciens SCSIO 00856
}

\author{
Cheng-Hai Gao ${ }^{1,2}$, Xin-Peng Tian ${ }^{1}$, Shu-Hua Qi ${ }^{1}$, Xiong-Ming Luo ${ }^{1}$, Ping Wang ${ }^{1,2}$ and Si Zhang ${ }^{1}$
}

The Journal of Antibiotics (2010) 63, 191-193; doi:10.1038/ja.2010.7; published online 12 February 2010

Keywords: antibacterial; antilarval; Bacillus amyloliquefaciens; Macrolactin V

It is well understood that corals harbor diverse microbial communities. Recently, many coral-associated bacteria have been characterized as sources of marine natural products, especially as the coral surface is more nutrient rich than seawater or even sediments. ${ }^{1,2}$ Colonization of coral surfaces by bacteria and other microorganisms is mostly nondestructive to corals. Owing to the close spatial vicinity of these biofilm-forming bacteria, it can be expected that the indigenous microbial population is adapted to competitive conditions. $^{3}$ The production of secondary metabolites is a common adaptation of these bacteria to compete in such microenvironments. There have been few reports documented on exploration of coralassociated bacteria in the South China Sea as a source of secondary metabolites.

In order to obtain biologically active natural products from coral-associated bacteria, we studied the marine bacterium Bacillus amyloliquefaciens SCSIO 00856 isolated from the South China Sea gorgonian Junceella juncea. In the preliminary experiments, we found that the culture broth of the strain had strong antibacterial activity towards three bacteria (Escherichia coli, Bacillus subtilis, and Staphyloccocus aureus) and antilarval activity towards laboratory-reared bryozoan Bugula neritina larvae. In this study, a new 24-membered ring lactone, macrolactin $\mathrm{V}$ (1) (Figure 1), together with four known compounds, macrolactin S (2), ${ }^{4}$ 4-butoxyphenol (3), ${ }^{5}$ 4-propoxyphenol (4), ${ }^{6}$ and 4 -ethoxyphenol $(5),{ }^{6}$ was isolated from a culture broth of the strain. Macrolactins are polyene macrolides containing a 24-membered lactone ring. About 20 macrolactins have been chemically characterized, including macrolactins A-U, 7-O-succinyl macrolactin $\mathrm{A}$, and 7-O-succinyl macrolactin F, from marine Bacillus sp. sediment isolate, and 7-O-malonyl macrolactin A from Bacillus subtilis soil isolate. ${ }^{4,7-13}$ Some of these compounds showed strong antibacterial, anti-tumor, and antivirus activities. ${ }^{4,7,9-13}$ The antibacterial activity of 1-5 against four bacterial strains and the antilarval activity of 3-5 against larval settlement of Bugula neritina and Balanus amphitrite larvae were evaluated. This paper deals with the isolation, structural elucidation of 1 and biological activity of 1-5.

The producing strain, Bacillus amyloliquefaciens SCSIO 00856, was isolated from the gorgonian coral Junceella juncea in Sanya, Hainan province, China. The strain culture $(2 \mathrm{ml})$ was used to inoculate $50 \mathrm{ml}$ seed medium consisting of $0.4 \%$ yeast extract, $0.4 \%$ glucose, $0.5 \%$ malt meal, and $1.8 \%$ sea salt ( $\mathrm{pH} 7.3$ ), in a $250-\mathrm{ml}$ flask. A volume of $20 \mathrm{ml}$ of the resulting culture was used to inoculate $400 \mathrm{ml}$ of the seed medium, in a 1-1 flask. The culture was incubated at $27^{\circ} \mathrm{C}$ on a rotary shaker operating at 150 r.p.m. for 5 days. The resulting $400-\mathrm{ml}$ culture was used to inoculate $120 \mathrm{l}$ of production medium, in a $200-1$ fermenter, containing the following components per liter of water: yeast extract $4 \mathrm{~g}$, malt meal $5 \mathrm{~g}$, glucose $4 \mathrm{~g}$, and sea salt $18 \mathrm{~g}$. The production fermentation tanks were operated at $27^{\circ} \mathrm{C}$, a back-pressure of $0.1 \mathrm{MPa}$, and an agitation rate of 150 r.p.m. pH was controlled at 7.3 by addition of $\mathrm{NaOH}$. The fermenter was operated for 10 days, at which time the culture was harvested for isolation of metabolites. The culture broth (1201) was extracted with EtOAc. The EtOAc extract was concentrated in vacuo to afford $13.9 \mathrm{~g}$ of residue, which was subjected to column chromatography $(\mathrm{CC})$ on silica gel, using $\mathrm{CHCl}_{3^{-}}$ $\mathrm{MeOH}$ (from 10:0 to 0:10) as eluent. Elution of CC with $8 \% \mathrm{MeOH}$ in $\mathrm{CHCl}_{3}$ gave a fraction of $835 \mathrm{mg}$. The fraction was subsequently subjected to $\mathrm{CC}$ on silica gel, eluted with $\mathrm{CHCl}_{3}-\mathrm{MeOH}$, then purified with semi-preparative HPLC (Luna C18(2), $250 \times 10 \mathrm{~mm}$ i.d., $5 \mathrm{ml} \mathrm{min}{ }^{-1}$ ), using $\mathrm{MeOH}$-water (65:35) as eluent to yield $\mathbf{1}(2.6 \mathrm{mg})$ and $\mathbf{2}(19.7 \mathrm{mg})$. Elution of the first CC with $20 \% \mathrm{MeOH}$ in $\mathrm{CHCl}_{3}$ gave a $342-\mathrm{mg}$ fraction, which was rechromatographed on a silica gel column using a gradient elution of $\mathrm{CHCl}_{3}-\mathrm{MeOH}$ to yield $3(60 \mathrm{mg})$. The fraction $(163 \mathrm{mg})$ eluted with $35 \% \mathrm{MeOH}$ in $\mathrm{CHCl}_{3}$ at the first $\mathrm{CC}$ was repeatedly subjected to silica gel column using a gradient elution of $\mathrm{CHCl}_{3}-\mathrm{MeOH}$ to yield $4(7.5 \mathrm{mg})$ and $\mathbf{5}(7.0 \mathrm{mg})$. The structures

\footnotetext{
${ }^{1}$ Key Laboratory of Marine Bio-resources Sustainable Utilization/Guangdong Key Laboratory of Marine Materia Medica, South China Sea Institute of Oceanology, The Chinese Academy of Sciences, Guangdong, China and ${ }^{2}$ Graduate School of the Chinese Academy of Sciences, Beijing, PR China

Correspondence: Dr S-H Qi, South China Sea Institute of Oceanology, The Chinese Academy of Sciences, 164 West Xingang Road, Guangzhou 510301, China. E-mail: shuhuaqi2001@yahoo.com
}

Received 26 September 2009; revised 10 January 2010; accepted 13 January 2010; published online 12 February 2010 


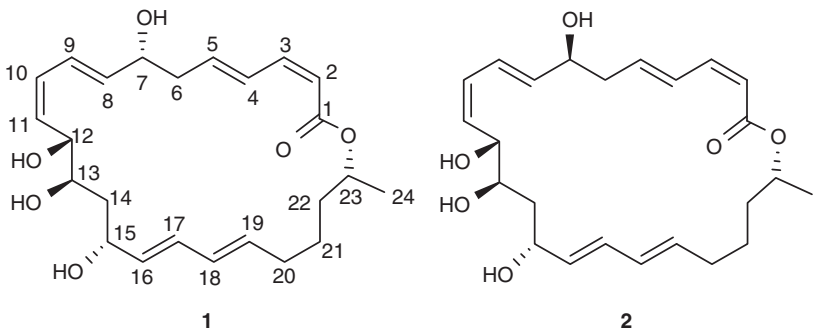

Figure 1 Structures of 1 and 2 .

Table $1{ }^{1} \mathrm{H}(500 \mathrm{MHz})$ and ${ }^{13} \mathrm{C}(125 \mathrm{MHz})$ NMR data of 1 and 2 in $\mathrm{CD}_{3} \mathrm{OD}$

\begin{tabular}{|c|c|c|c|c|}
\hline \multirow[b]{2}{*}{ Position } & \multicolumn{2}{|l|}{1} & \multicolumn{2}{|l|}{2} \\
\hline & $\delta_{H}$, mult $(\mathrm{J}$ in $\mathrm{Hz})$ & $\delta_{C}$ & $\delta_{H}$, mult $(\mathrm{J}$ in $\mathrm{Hz})$ & $\delta_{C}$ \\
\hline 1 & & $167.8 \mathrm{C}$ & & $167.8 \mathrm{C}$ \\
\hline 2 & $5.58 \mathrm{~d}(12.0)$ & $118.4 \mathrm{CH}$ & $5.58 \mathrm{~d}(12.0)$ & $117.9 \mathrm{CH}$ \\
\hline 3 & $6.66 \mathrm{dd}(11.5,11.5)$ & $145.0 \mathrm{CH}$ & $6.66 \mathrm{dd}(11.5,11.5)$ & $145.4 \mathrm{CH}$ \\
\hline 4 & $7.25 \mathrm{dd}(11.5,15)$ & $130.4 \mathrm{CH}$ & $7.25 \mathrm{dd}(11.5,15)$ & $129.9 \mathrm{CH}$ \\
\hline 5 & $6.13 \mathrm{~m}$ & $140.3 \mathrm{CH}$ & $6.13 \mathrm{~m}$ & $142.1 \mathrm{CH}$ \\
\hline 6 & $2.57 \mathrm{~m}$ & $39.7 \mathrm{CH}_{2}$ & $2.47 \mathrm{~m}$ & $42.6 \mathrm{CH}_{2}$ \\
\hline 7 & $5.38 \mathrm{~m}$ & $75.7 \mathrm{CH}$ & $4.18 \mathrm{~m}$ & $73.6 \mathrm{CH}$ \\
\hline 8 & $5.75 \mathrm{dd}(7.5,15.0)$ & $138.5 \mathrm{CH}$ & $5.75 \mathrm{dd}(7.5,15.0)$ & $138.8 \mathrm{CH}$ \\
\hline 9 & $6.60 \mathrm{dd}(11.5,15.0)$ & $130.0 \mathrm{CH}$ & $6.60 \mathrm{dd}(11.5,15.0)$ & $127.4 \mathrm{CH}$ \\
\hline 10 & $6.15 \mathrm{~m}$ & $130.6 \mathrm{CH}$ & $6.15 \mathrm{~m}$ & $130.6 \mathrm{CH}$ \\
\hline 11 & $5.57 \mathrm{~m}$ & $132.8 \mathrm{CH}$ & $5.57 \mathrm{~m}$ & $131.5 \mathrm{CH}$ \\
\hline 12 & $4.51 \mathrm{~m}$ & $72.4 \mathrm{CH}$ & $4.51 \mathrm{~m}$ & $72.4 \mathrm{CH}$ \\
\hline 13 & $4.03 \mathrm{~m}$ & $72.9 \mathrm{CH}$ & $4.03 \mathrm{~m}$ & $73.0 \mathrm{CH}$ \\
\hline 14 & $2.60 \mathrm{~m}$ & $39.7 \mathrm{CH}_{2}$ & $2.60 \mathrm{~m}$ & $39.7 \mathrm{CH}_{2}$ \\
\hline 15 & $4.31 \mathrm{~m}$ & $69.0 \mathrm{CH}$ & $4.31 \mathrm{~m}$ & $69.0 \mathrm{CH}$ \\
\hline 16 & $5.62 \mathrm{~m}$ & $135.5 \mathrm{CH}$ & $5.62 \mathrm{~m}$ & $135.5 \mathrm{CH}$ \\
\hline 17 & $6.10 \mathrm{dd}(10.5,15.0)$ & $130.7 \mathrm{CH}$ & $6.10 \mathrm{dd}(10.5,15.0)$ & $130.9 \mathrm{CH}$ \\
\hline 18 & $5.57 \mathrm{dd}(10.5,15.0)$ & $131.8 \mathrm{CH}$ & $5.57 \mathrm{dd}(10.5,15.0)$ & $131.8 \mathrm{CH}$ \\
\hline 19 & $5.56 \mathrm{~m}$ & $134.8 \mathrm{CH}$ & $5.56 \mathrm{~m}$ & $134.8 \mathrm{CH}$ \\
\hline \multirow[t]{2}{*}{20} & $2.09 \mathrm{~m}$ & $32.7 \mathrm{CH}_{2}$ & $2.09 \mathrm{~m}$ & $32.7 \mathrm{CH}_{2}$ \\
\hline & $2.24 \mathrm{~m}$ & & $2.24 \mathrm{~m}$ & \\
\hline 21 & $1.53 \mathrm{~m}$ & $25.5 \mathrm{CH}_{2}$ & $1.53 \mathrm{~m}$ & $25.4 \mathrm{CH}_{2}$ \\
\hline \multirow[t]{2}{*}{22} & $1.56 \mathrm{~m}$ & $36.0 \mathrm{CH}_{2}$ & $1.56 \mathrm{~m}$ & $36.0 \mathrm{CH}_{2}$ \\
\hline & $1.65 \mathrm{~m}$ & & $1.65 \mathrm{~m}$ & \\
\hline 23 & $5.08 \mathrm{~m}$ & $71.7 \mathrm{CH}$ & $5.08 \mathrm{~m}$ & $71.6 \mathrm{CH}$ \\
\hline 24 & $1.25(\mathrm{~d}, 6.0)$ & $20.2 \mathrm{CH}_{3}$ & $1.25(\mathrm{~d}, 6.0)$ & $20.2 \mathrm{CH}_{3}$ \\
\hline
\end{tabular}

of 3-5 were established by analyzing their 1D NMR spectral data and by comparison with the literature. ${ }^{5,6}$

Compound 1 had the molecular formula of $\mathrm{C}_{24} \mathrm{H}_{34} \mathrm{O}_{6}$ as deduced from NMR spectra and HR-ESI-MS. The ${ }^{1} \mathrm{H}$ NMR spectrum showed signals for one methyl group at $\delta_{\mathrm{H}} 1.25(3 \mathrm{H}, \mathrm{d}, J=6.0 \mathrm{~Hz}), 12$ olefinic protons and five oxymethine protons at the chemical shift downfield of $\delta_{\mathrm{H}} 4.03-7.25$ (Table 1). Its ${ }^{13} \mathrm{C}$ NMR spectrum showed the presence of one methyl, five methylenes, six 1,2-disubstituted double bonds, five oxymethines, and a carbonyl group $\left(\delta_{\mathrm{C}} 167.8\right)$ (Table 1). These ${ }^{1} \mathrm{H}$ and ${ }^{13} \mathrm{C}$ NMR data of $\mathbf{1}$ were very similar to those of macrolactin $\mathrm{S}$ $(2)^{4}$ (Table 1). Extensive analyses of the ${ }^{1} \mathrm{H}$ NMR, ${ }^{13} \mathrm{C}$ NMR, HSQC, $\mathrm{HMBC}$ (Figure 2), and ${ }^{1} \mathrm{H}-{ }^{1} \mathrm{H}$ COSY spectra of $\mathbf{1}$ inferred that $\mathbf{1}$ should have the same chemical planar structure as 2 . In the ${ }^{1} \mathrm{H}$ NMR spectrum of 1 , the ${ }^{1} \mathrm{H}$ coupling constants of $\mathrm{H}-2 / \mathrm{H}-3(J=11.5 \mathrm{~Hz})$, H-4/H-5 $(J=15.0 \mathrm{~Hz}), \mathrm{H}-8 / \mathrm{H}-9(J=15.0 \mathrm{~Hz}), \mathrm{H}-10 / \mathrm{H}-11(J=10.0 \mathrm{~Hz})$,

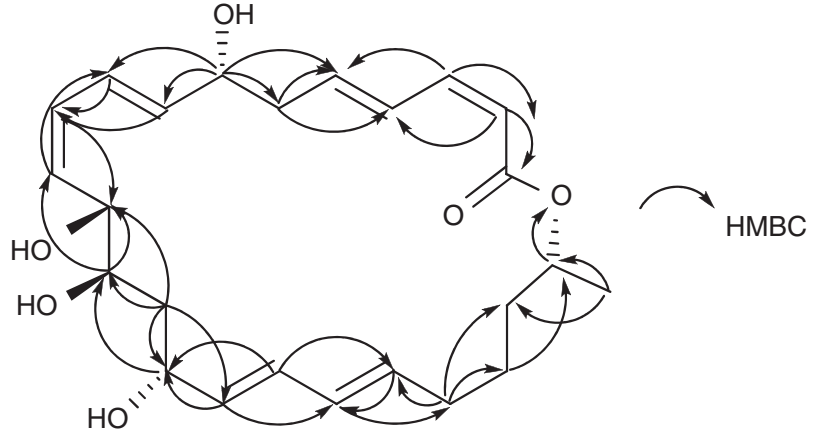

Figure 2 Key HMBC correlations of 1.

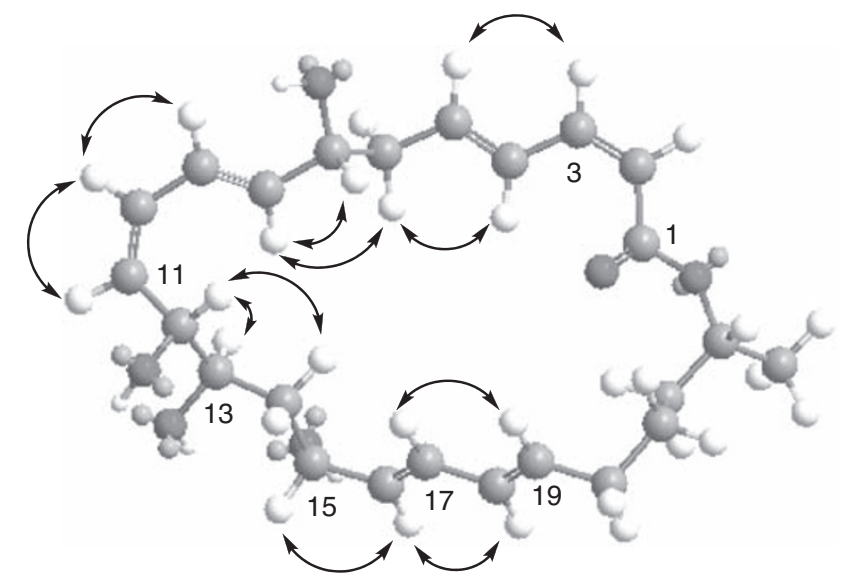

Figure 3 Key NOESY correlations of 1 .

$\mathrm{H}-16 / \mathrm{H}-17(J=15.0 \mathrm{~Hz})$, and $\mathrm{H}-18 / \mathrm{H}-19(J=15.0 \mathrm{~Hz})$ indicated that geometric configurations of 1 were $2 Z, 4 E, 8 E, 10 Z, 16 E, 18 E$. The ${ }^{1} \mathrm{H}$ and ${ }^{13} \mathrm{C}$ NMR data of $\mathrm{H}-12 / \mathrm{C}-12, \mathrm{H}-13 / \mathrm{C}-13, \mathrm{H}-15 / \mathrm{C}-15$, and $\mathrm{H}-23 / \mathrm{C}-23$ in 1 were almost the same as those in 2 , which suggested that the stereochemistry of chiral carbons C-12, C-13, C-15, and C-23 was the same as that in 2 .

However, compared with the ${ }^{1} \mathrm{H}$ and ${ }^{13} \mathrm{C}$ NMR data of 2, the downfield shift of H-6 (from $\delta_{\mathrm{H}} 2.47$ in 2 to $\delta_{\mathrm{H}} 2.57$ in 1 ), H-7 (from $\delta_{\mathrm{H}} 4.18$ to $\delta_{\mathrm{H}} 5.38$ ), C-7 (from $\delta_{\mathrm{C}} 73.6$ to $\delta_{\mathrm{C}} 75.7$ ), and C-9 (from $\delta_{\mathrm{C}}$ 127.4 to $\delta_{\mathrm{C}} 130.0$ ), and upfield shift of C-5 (from $\delta_{\mathrm{C}} 142.1$ to $\delta_{\mathrm{C}}$ 140.3 ) and C-6 (from $\delta_{\mathrm{C}} 42.6$ to $\delta_{\mathrm{C}} 39.7$ ) were obviously observed in the NMR spectra of 1 , which should be caused by the change of the three-dimensional effect at C-7 position, and suggested that the configuration of $-\mathrm{OH}$ at $\mathrm{C}-7$ in $\mathbf{1}$ should be $\alpha$-configuration instead of $\beta$-configuration as it existed in $\mathbf{2}$ and other previously isolated macrolactins. ${ }^{4,7-13}$ The suggestion was supported by the NOESY (Figure 3), in which NOE correlations of $\mathrm{H}-6 \beta$ with $\mathrm{H}-8 / \mathrm{H}-4$ and $\mathrm{H}-7$ with $\mathrm{H}-8$ were observed, whereas no NOE correlations between $\mathrm{H}-7$ and $\mathrm{H}-9 / \mathrm{H}-5$ were observed, which were in agreement with the MM2 optimized conformation of 1 . However, NOE correlations of H-7 with H-9/H-5 were obviously observed in the NOESY of $2 .{ }^{4}$ Thus, the structure of $\mathbf{1}$ was determined as shown and named macrolactin $\mathrm{V}$. The optical rotation value of $\mathbf{1}$ is -0.08 (c $0.11, \mathrm{MeOH})$, which is different from that of $2(-0.62(\mathrm{c} 0.15, \mathrm{MeOH})){ }^{4}$

The antibacterial activity of compounds $\mathbf{1 - 5}$ was measured against E. coli, Bacillus thuringiensis, Bacillus subtilis, and S. aureus using standard disc diffusion assay. ${ }^{14}$ The MICs of compound 1-5 were 
determined by a dilution method. ${ }^{15}$ The results showed that macrolactin V (1) had strong antibacterial activity against E. coli, Bacillus subtilis, and $S$. aureus, with an MIC value of $0.1 \mu \mathrm{g} \mathrm{ml}^{-1}$, and no activity against Bacillus thuringiensis, and macrolactin S (2) showed strong antibacterial activity against $E$. coli and $S$. aureus with MIC values of 0.3 and $0.1 \mu \mathrm{g} \mathrm{ml}^{-1}$, respectively, but weak activity against Bacillus subtilis (MIC $100 \mu \mathrm{g} \mathrm{ml}^{-1}$ ), which indicated that the configuration of $\mathrm{OH}-7$ could affect the antibacterial activity of the epimers 1 and 2. Compounds 3-5 showed no or weak inhibition towards all tested bacteria.

The antilarval activity of compounds 3-5 was evaluated in settlement inhibition assays with laboratory-reared Bugula neritina (Bryozoa) and Balanus amphitrite (Cirripedia) larvae. The procedures were the same as previously reported. ${ }^{16}$ Larval settlement bioassays revealed that 3-5 showed potent antilarval activity towards Bacillus amphitrite larvae with $\mathrm{EC}_{50}$ values of $23.0,22.9$, and $24.1 \mu \mathrm{g} \mathrm{ml}^{-1}$, respectively. However, only 3 could inhibit Bacillus neritina larvae settlement at the concentration of $50 \mu \mathrm{g} \mathrm{ml}^{-1}$, but no activity at $25 \mu \mathrm{g} \mathrm{ml}^{-1}$, and 4 and 5 were inactive even at $50 \mu \mathrm{g} \mathrm{ml}^{-1}$. The $\mathrm{EC}_{50}$ values of $\mathbf{3 - 5}$ against Bacillus amphitrite larvae settlement were lower than the standard requirement of an $\mathrm{EC}_{50}$ of $25 \mu \mathrm{g} \mathrm{ml}^{-1}$ established by the US Navy program as an efficacy level for natural antifoulants, indicating that 3-5 are potential selective natural antifouling agents. This was the first time to report 3-5 from culture broths of bacteria and their antilarval activities against marine invertebrate larvae.

\section{EXPERIMENTAL PROCEDURE}

\section{Taxonomy}

Blast search results at EzTaxon.org Server showed that the 16S rRNA gene sequence of the strain SCSIO 00856 has the highest similarity (99.21\%) with Bacillus amyloliquefaciens ATCC $23350^{\mathrm{T}}$. On the basis of the morphological features and the 16S rRNA gene sequence, the strain SCSIO 00856 was identified as Bacillus amyloliquefaciens and named Bacillus amyloliquefaciens SCSIO 00856. It was deposited at the Guangdong Key Laboratory of Marine Materia Medica, South China Sea Institute of Oceanology, The Chinese Academy of Sciences, China (Accession No. SCSIO 00856).

\section{Physico-chemical properties}

Macrolactin V: yellow oil; $[\alpha]_{\mathrm{D}}{ }^{20}-0.08^{\circ}$ (c $\left.0.11, \mathrm{MeOH}\right), \mathrm{UV}(\mathrm{MeOH}) \lambda_{\max }$ $(\log \varepsilon) 229$ (4.57), $261(4.18) \mathrm{nm}$; IR (KBr): 3295, 1700, $1667 \mathrm{~cm}^{-1}$; for ${ }^{1} \mathrm{H}$ and ${ }^{13} \mathrm{C}$ NMR data, see Table 1; HR-ESI-MS $m / z$ : $[\mathrm{M}+\mathrm{H}]^{+} 419.2357$ (calcd. for $\mathrm{C}_{24} \mathrm{H}_{35} \mathrm{O}_{6}$ : 419.2355).

\section{ACKNOWLEDGEMENTS}

We are grateful to the Knowledge Innovation Program of the Chinese Academy of Science (grant KZCX2-YW-216-1), the National Basic Research Program of China (grant 2010CB833800-G), the National Natural Science Foundation of China and Research Grants Council of Hong Kong (NSFC/RGC) Program (grant 40910093), and the Knowledge Innovation Program of the South China Sea Institute of Oceanology, Chinese Academy of Sciences (grant LYQY200703) for financial support.

1 Moore, B. S. Biosynthesis of marine natural products-microorganisms and macroalage. Nat. Prod. Rep. 16, 653-674 (1999).

2 Radjasa, O. K. Marine invertebrate-associated bacteria in coral reef ecosystems as a new source of bioactive compounds. J. Coast. Dev. 7, 65-70 (2004).

3 Slattery, M., Rajbhandari, I. \& Wesson, K. Competition-mediated antibiotic induction in themarine bacterium Streptomyces tenjimariensis. Microb. Ecol. 41, 90-96 (2001).

$4 \mathrm{Lu}, \mathrm{X}$. L. et al. Macrolactin S, a novel macrolactin antibiotic from marine Bacillus sp. Nat. Prod. Res. 22, 342-347 (2008).

5 Green, J., Marcinkiewicz, S. \& McHale, D. Paper chromatography and chemical structure. III. The correlation of complex and simple molecules. The calculation of $\mathrm{RM}$ values for tocopherols, vitamins $\mathrm{K}$, ubiquinones, and ubichromenols from RM (phenol). Effects of unsaturation and chain branching. J. Chromatogr. 10, 158-183 (1963).

6 Gouws, S., Barton, B., Loyson, P. L. R. \& Zeelie, B. Electrochemical production of alkoxy-substituted phenols. Electrochim. Acta 53, 4544-4549 (2008).

7 Gustafson, K., Roman, M. \& Fenical, W. The macrolactins, a novel class of antiviral and cytotoxic macrolides from a deep-sea marine bacterium. J. Am. Chem. Soc. 111, 7519-7524 (1989).

8 Rychnovsky, S. D., Skalitzky, D. J., Pathirana, C., Jensen, P. R. \& Fenical, W. J. Stereochemistry of the macrolactins. J. Am. Chem. Soc. 114, 671-677 (1992).

9 Nagao, T., Adachi, K., Sakai, M., Nishijima, M. \& Sano, H. Novel macrolactins as antibiotic lactones from a marine bacterium. J. Antibiot. 54, 333-339 (2001).

10 Yoo, J. S., Zheng, C. J., Lee, S., Kwak, J. H. \& Kim, W. G. Macrolactin N, a new peptide deformylase inhibitor produced by Bacillus subtilis. Bioorg. Med. Chem. Lett. 16, 4889-4892 (2006).

11 Jaruchoktaweecha, C., Suwanborirux, K., Tanasupawatt, S., Kittakoop, P. \& Menasveta, P. New macrolactins from a marine Bacillus sp. Sc026. J. Nat. Prod. 63, 984-986 (2000).

12 Taharez, M. R. et al. 7-O-Malonyl macrolactin A, a new macrolactin antibiotic from Bacillus subtilis active against methicillin-resistant Staphylococcus aureus, vancomycin-resistant Enterococci, and a small-colony variant of Burkholderia cepacia. Antimicrob. Agents Chemother. 50, 1701-1709 (2006).

13 Xue, C. M., Tian, L., Xu, M. J., Deng, Z. W. \& Lin, W. H. A new 24-membered lactones and a new polyene $\delta$-lactone from the marine bacterium Bacillus marinus. J. Antibiot. 61, 668-674 (2008)

14 Acar, J. F. The disc susceptibility test. in Antibiotics in Laboratory Medicine (ed. Lorian, V.) 24-54 (Williams \& Wilkins, Baltimore, 1980).

15 Brantner, A. \& Grein, E. Antibacterial activity of plant extracts used externally in traditional medicine. J. Ethnopharmacol. 44, 35-40 (1994).

16 Qi, S. H., Zhang, S., Qian, P. Y. \& Wang, B. G. Antifeedent, antibacterial, and antilarval compounds from the South China Sea seagrass Enhalusacroroides. Bot. Marina. 51, 441-447 (2008). 